\title{
Metode Komunikasi Dakwah Majelis Ulama Indonesia (MUI) Dalam Mengatasi Paham Radikal Di Kabupaten Labuhanbatu
}

\begin{abstract}
ABSTRAK
This research is motivated by the rise of radicalism ideology lately, especially in one of the organizations in the city of Rantau Prapat. The purpose of this study was to find out the dangers of radical understanding conveyed by Muhamamd Gaddafi and members of the Islamic Generation Study Circle (LSGI) to the Labuhanbatu Rantauprapat community and the application of MUI da'wah communication methods in overcoming radical LSGI understanding in Labuhanbatu, and how the Indonesian Ulema Council in overcoming obstacles. - Barriers to the communication of the da'wah. This research uses qualitative research. Data were collected by interview, observation, documentation and literature review. This research was analyzed inductively. The results obtained show that the Labuhanbatu MUI has succeeded in reducing the expansion of radical understanding brought by Muhammad Gaddafi and members of the LSGI in Labuhanbatu Rantauprapat, by applying the da'wah communication method, with this success it is expected to there will be no more people who are tempted by this radical understanding. MUI itself has provided guidance to Muhammad Gaddafi and members of the LSGI by applying the da'wah communication method, the public is no longer restless and afraid of the spread of this understanding, because they are no longer radical
\end{abstract}

Keywords: Communication method; radical understanding.

\section{PENDAHULUAN}

Pada hakekatnya tujuan hidup manusia adalah mencapai kebahagiaan hidup di dunia maupun di akhirat kelak. Untuk mencapai tujuan itu didalam Islam dapat dicapai melalui ibadah. Ibadah adalah kewajiban bagi setiap muslim, dan merupakan prinsip hidup yang hakiki, sehingga perilaku muslim senantiasa mencerminkan penempatan pengabdian di dalam kehidupan sehari-hari. Sedangkan pengabdian itu sendiri merupakan penyerahan mutlak kepada Tuhan secara lahiriah dan batiniah terhadap aturan-aturan yang telah ditetapkan oleh Allah SWT. Dengan kata lain semua ibadah yang bersifat ubudiah dan bersifat muamalah harus dilakukan dalam rangka mencapai Ridho Allah. Oleh 
karena itu apa yang kita kerjakan dan yang kita usahakan dalam hidup ini adalah ibadah, selama pelaksanaannya tidak menyimpang dari ajaran Islam. Firman Allah dalam surat Adz-dzariat ayat 56, yang berbunyi (Kementerian Agama RI, 2007):

Artinya:" Dan aku (Allah) tidak akan menjadikan Jin dan Manusia supaya mereka mengabdi kepada ku".

Pada prinsipnya Islam mengajarkan keseimbangan antara kewajiban bekerja dan kewajiban ubudiah dalam sikap dan demikian sebaliknya. Karena itu Islam menganjurkan beribadah kepada Allah SWT bukan berarti harus menjauhi dan meninggalan kehidupan dunia dan hanya mengejar akhirat saja, akan tetrapi dunia adalah sebagai alat menuju akhiratnya, bukan sebagai tujuan akhir, dan telah menjadi kenyataan bahwa orang-orang Islam menghadapi berbagai masalah dan bermacam-macam kesulitan di samping keseimbangan perseorangan, maka diselubungi dengan kesulitan-kesulitan dan kesukaran-kesukaran umum yang menimpa suatu masyarakat.

Padahal Islam agama yang telah lengkap dan sempurna. Allah Ta"eala mengisyaratkan kelengkapannya di dalam $\mathrm{Al}$ quran dan mengumumkan dengan penyempurnaannya. Allah telah melengkapkan nikmatnya dan rahmatnya keatas manusia. Betapa besarnya penghormatan dan ketinggian yang dianugerahkan kepada orang-orang Islam, tetapi malangnya pengikut-pengikut atau penganut-penganut dari agama yang sempurna ini masih bingung dengan apa yang seharusnya untuk dilakukan. Kerusakan kemaksiatan merajalela, perzinahan dijadikan sebagai keteladanan, minuman keras menjadi dambaan dan peristiwa-peristiwa yang menyedihkan turut mengiringinya.

Islam adalah agama perdamaian, perdamaian termasuk salah satu prinsip yang selalu diajarkan dalam Islam agar kuat tertanam dalam benak setiap muslim. Hal itu menjadikan perdamaian sebagai salah satu bahagian kepribadian dan akidah seorang muslim. Islam, dari awal sudah mengajak dan memperjuangkan perdamain keseluruh penjuru dunia. Islam juga sudah membuat teori yang dapat membawa manusia kepada perdamaian.

Islam sangat mencintai dan mensucikan kehidupan. Kemuadian Islam juga mengajak manusia untuk mencintai kehidupannya. Kata "Islam”, nama agama ini berasal dari kata "salam" yang berarti perdamaian. Berarti Islam dapat memberikan keamanan, kedamaian, ketenangan, dan ketenteraman. Dengan demikian masih ada beberapa orang atau kelompok yang menggunakan kata "salam" ini sebagai alat kekerasan untuk mencapai tujuan mereka, kelompok mereka sering dikenal dengan 
Radikalisme (Sabiq, 2015). Gerakan radikalisme sesungguhnya bukan sebuah gerakan yang muncul begitu saja tetapi memiliki latar belakang yang sekaligus menjadi faktor pendorong munculnya gerakan radikalisme yang terdiri dari dua fakto yaitu Faktor sosio-politik dan faktor cultural (Sumbala, 2010).

Rantau Prapat adalah salah satu kota yang kecil terdiri dari dua kecamatan yaitu: Rantau Utara dan Rantau Selatan, masyarakat setempat menggantungkan hidupnya dengan bercocok tanam seperti menanam pohon kelapa sawit dan berdagang, sedangkan dari segi spritualismenya $50 \%$ mereka memegang paham tua, 30\% memegang paham muda, dan $20 \%$ nya lagi tidak perduli dengan hubungan akhirat. Kota kecil ini juga memiliki Majelis Ulama Indonesia (MUI) Labuhanbatu Rantauprapat yang delegasinya sangat mempengaruhi kehidupan masyarakat setempat peran dan kontrobusinya sangat bernilai positif.

Peneliti mendatangi kantor MUI Labuhanbatu Rantauprapat dan menayakan sedikit pertanyaan mengenai apa pendapat MUI Labuhanbatu Rantauprapat mengenai radikalisme. Untuk mendapatkan jawaban ini peneliti mendatangi seketarisnya yang kebetulan peneliti kenal dengan seketaris MUI Labuhanbatu Rantauprapat beliau bernama Drs. H.Abdul Hamid Zaid. Bapak Drs. Beliau menjelaskan bahwa radikalisme adalah sebuah kelompok yang ekstrimis, kelompok yang memiliki ideologi sendiri dan bertentangan dengan ideologi negara, kelompok ini berbeda dengan kelompok agama karena agama mengajarkan kedamaian sedangkan kelompok radikal menciptakan kerusakan dan permusuhan, tutur beliau.

Ditahun 2015 peneliti pernah mengikuti sebuah organisasi yang bernama LSGI (Lingkar Study Generasi Islam). Organisasi ini di didirikan pada tanggal 14 juni 2012 oleh Muhammad Kadhafi selaku pendiri organisasi tersebut. Dan berdomisili di Rantauprapat yang beralamat di jalan Binaraga Labuhanbatu, organisasi ini sudah ditandai garis merah oleh MUI, karena ada laporan masyarakat tentang isi dari pengajian organisasi itu menimbulkan perselisihan mengenai pemahaman tentang sistem kenegaraan yang dipakai Indonesia dan tidak perlu Undangundang dari Indonesia.

Ditahun 2015 itu juga peneliti masuk organisasi dan ditetapkan sebagai relawan setelah tiga bulan mengikuti pengajian di organisasi itu, sebelum jadi relawan peneliti mendapat materi tentang ketauhitan, muamalah, dan aqidah sama dengan apa yang disampaikan oleh ustad-ustad pada umumnya, setelah tiga bulan itu berlalu maka masuk kepada materi sistem kenegaraan yang benar menurut Alquran dan Hadis yang semua itu mereka tafsirkan sendiri. Materi yang disampaikan itu pada hakikatnya tidak membenarkan sistem yang dipakai oleh NKRI dan lebih cenderung kepada 
khilafah, tapi mereka bukan HTI. Sebagai contoh ayat yang mereka tafsirkan sendiri adalah dalam surah An-nisa ayat 60 dan 76(Kementerian Agama RI, 2007):

Artinya: Tidaklah engkau (Muhammad) memperhatikan orangorang yang mengaku bahwa mereka telah beriman kepada apa yang diturunkan kepadamu dan kepada apa yang diturunkan sebelummu, tetapi mereka masih menginginkan ketetapan hukum kepada thagut padahal mereka telah diperintahkan untuk memerangi thogut itu. Dan setan bermaksud menyesatkan mereka dengan kesesatan yang sejauh-

jauhnya. (Q.S An-nisa: 60)

dan Artinya: Orang-orang beriman, mereka berperang di jalan Allah, dan orang- orang kafir berperang di jalan thogut, maka perangilah kawan-kawan setan itu, karena sesungguhnya tipu daya setan itu lemah. (Q.S An-nisa: 76)

Kedua ayat ini tidak ada salahnya, akan tetapi yang salah itu ketika ayat ini ditafsirkan oleh LSGI sesuai dengan pendapat mereka yang menentang sistem pemerintahan Indonesia, Mereka bukan melihat dari ulama-ulama tafsir yang sudah diakui ummat Islam, ayat di atas menyatakan tentang thogut yang mereka maksud thogut pada kedua ayat itu adalah sesuatu yang bukan bersumber dari hukum Allah dan tidak ada ketaatan dalam thogut. NKRI mempunyai dasar Negara Pancasila dan Undang-undang Dasar 1945, kedua dasar ini bukan dari Allah melainkan buatan manusia. Maka NKRI disebut mereka sistem thogut.

Peneliti melihat LSGI ini memang organisasi, tapi tentang ideologi mereka sangat berbahaya dalam menjaga kerukunan ummat beragama khususnya di Labuhanbatu Rantauprapat, dan sangat berbahaya lagi untuk generasi muda yang belum mengenal Islam dan terpengaruh dengan pemahaman mereka, dan memang target dari penyebaran pemahaman mereka adalah ganerasi muda seperti anak SMA dan SMP.

Hari terus berjalan dan peneliti mengikuti materi yang disampaikan, dalam hati peneliti sebenarnya ada rasa ragu tapi keingin tahuan itu sangat tinggi maka peneliti terus mengikuti taklim itu. Sesuai dengan ayat di atas, isi dari taklim itu adalah mengenai sistem pemerintah yang sudah tidak bisa lagi diikuti dan harus keluar dari sitem ini kalau tidak nanti kita bisa dikatakan taat sama thogut (sesuatu yang ditaati selian Allah) maka masuklah kita sebagai kategori kafir, dan juga mereka sangat membela ISIS sebagai perubahan islam.

Sebuah pemikiran yang menurut peneliti sangat berlawanan sama hati peneliti dengan materi yang telah disampaikan. Pada akhirnya penelitipun keluar dari organisasi itu dibimbing oleh Bapak Drs. H.Abdul 
Hamid Zaid beliau adalah kepala sekolah peneliti waktu duduk dibangku aliyah, setelah dibimbing terbukalah wawasan peneliti saat itu tentang Islam yang sebenarnya. Dan rasa peneliti organisasi ini sudah terindikasi sebagai paham radikalisme. Ekspansi LSGI di Labuhanbatu cukup lama dan pada akhirnya pada tanggal 14 maret 2019 oknum kepolisian dan MUI berhasih menghentikan dan membubarkan organisasi LSGI ini di Labuhanbatu. Nah dari sinilah peneliti akan melihat apa yang dilakukan MUI Labuhanbatu dalam mengatasi paham radikal di Labuhanbatu Rantauprapat dengan menggunakan metode komunikasi dakwah.

\section{METODE PENELITIAN}

Jenis penelitian dalam skripsi ini adalah penelitian kualitatif yaitu, penelitian yang berupaya menarik nilai-nilai data yang ditemui atau diperoleh di lapangan (Sugiyono, 2007). Menghasilkan data deskriptif berupa kata-kata tertulis maupun lisan dari orang-orang yang bersangkutan dan perilaku yang dapat diamati, yang mana disini berhubungan langsung dengan pelaksanaan dakwah yang dilakukan MUI dalam mengatasi paham radikal di Labuhanbatu Rantauprapat. Adapun yang akan menjadi sumber informan atau sumber data dalam penelitian ini adalah:

\begin{tabular}{|l|l|l|c|}
\hline No & \multicolumn{1}{|c|}{ Nama } & Jabatan & Usia \\
\hline 1 & Kh. Darwis husin. Lc & Ketua MUI Labuhanbatu & 61 Tahun \\
\hline 2 & Drs. H. Abdul Hamid Zaid & Seketaris MUI Labuhanbatu & 57 Tahun \\
\hline 3 & Drs. H. Abdul Halim Hasan.Mh & Seksi Dakwah MUI Labuhanbatu & 55 Tahun \\
\hline 4 & Bapak Syafruddin & Bagian Humas Polres Labuhanbatu & 50 Tahun \\
\hline
\end{tabular}

Data dalam penelitian ini dikumpulkan melalui wawancara, observasi, dan tinjauan pustaka. Secara keseluruhan analisis data dan penarikan kesimpulan dari pembahasan penelitian ini menggunakan metode komporatif, yaitu mengambil koneksi dari pembahasan dengan membandingkan dasar-dasar teoritis yang diperoleh dari literatur ilmiah dengan data yang diperoleh di lapangan (Sugiyono, 2007).

\section{HASIL PENELITIAN DAN PEMBAHASAN} Perkembangan Paham Radikal di Labuhanbatu 
Membahas tentang radikalisme adalah isu tentang terorisme dan anti kebinekaan serta anti pancasila, perkembangan radikal di Indonesia bukanlah hal yang baru untuk diperbincangkan, akan tetapi hal yang harus difikirkan adalah bagaimana strategi untuk membumihanguskan paham radikal di seluruh Negara, dan di Indonesia, terkusus di Labuhanbatu ini. Hasil wawancara peneliti dengan bapak Syafruddin bagian humas polres Labuhanbatu, bapak Syafruddin menyatakan:

"Bahwasanya perkembangan paham radikal di Labuhanbatu merupakan ancaman bagi seluruh elemen masyarakat terkhusus masyarakat Labuhanbatu. Sejauh ini paham radikal belum ada tindakan yang membahayakan masyarakat setempat, seperti melukai, ataupun melakukan aksi bom bunuh diri."

"Masuknya paham radikal di Labuhanbatu tidak kami ketahui dengan pasti, akan tetapi perkembangannya dimulai ditahun 2010, ketika penangkapan dua orang lelaki yang bernama Salamuddin dan Ahmad Rizal di daerah Sigambal, kronologi penangkapan bermula ketika saudara Salamuddin ditilang karena tidak memakai helem dan tidak membawa STNK kendaraan, langsung Salamuddin berkata "Saya pendukung ISIS di Labuhanbatu kalian para thogut tidak akan bisa menangkap kami, tutur beliau."

"Mendengar tutur kata saudara Salamuddin, pihak kepolisian langsung melumpuhkan beliau, dan mendatangi tempat kediaman saudara Salamuddin yang beralamat di Kampung Dalam Sigambal, setelah penggeledahan berlangsung densus 88 Labuhanbatu mengamankan satu lagi tersangka pendukung ISIS Labuhanbatu yang bernama Ahmad Rizal, banyak buku-buku yang mengarah kepada kekerasan dalam perspektif Islam, dan diamankan juga bendera dengan kalimat Tauhid yang di bawahnya ada tulisan ISIS. Dari situlah kasus awal perkembangan paham radikal sering mencuap kepermukaan.

Pernyataan di atas juga didukung oleh bapak KH. Darwis Husin LC, sebagai ketua MUI Labuhanbatu menyatakan:

"Menurut MUI Labuhanbatu ada beberapa faktor yang menyebabkan paham radikal berkembang di Labuhanbatu:

\section{Faktor Sosial-Politik}

Munculnya istilah Islam radikal dikarenakan penolakan terhadap gagasan pluralisme dan liberalisme agama. Menurut perspektif kelompok 
Islam radikal agama kristen dan yahudi paling memusuhi Islam, baik permusuhan yang dilakukan dengan kekerasan fisik maupun cultural. Sama seperti kasus Salamuddin dan Ahmad Rizal, mereka menganggap sistem pemerintahan di Indonesia tidak lagi berjalan sesuai dengan semestinya, mereka merasa Islam disudutkan dan tidak diperdulikan, seperti maraknya maksiat, banyaknya hiburan malam yang menyesatkan, dan pemerintah tidak bisa berbuat apa apa meski kekuasan ada ditangan mereka."

"Paham radikal di Labuhanbatu juga tidak mengakui UUD 45 dan Pancasila sebagai pedoman hidup, mereka menganggap itu sama saja mematuhi thogut dan siapa yang mematuhi thogut maka dia sudah murtad secara langsung. Ditahun 2010 kasus Salamuddin dan Ahmad Rizal, kasus berikutnya di Labuhanbatu adanya paham radikal di susupi oleh organisasi yang bernama LSGI (Lingkar Study Generasi Islam) yang di pimpin oleh Muhammad Khadafi, organisasi ini dibentuk ditahun 2012 dan resmi dibubarkan ditahun 2018.

Pernyataan di atas juga didukung oleh bapak DRS. H. Abdul Halim Hasan. MH, sebagai ketua seksi dakwah MUI Labuhanbatu menyatakan:

\section{Faktor Theoligi Islam}

"Islam sendiri memiliki perspektif dalam menata kehidupan ini, mampu membuat manusia berfikir secara logis dan jelas, sikap toleransi dan sikap tegas terhadap permasalahan yang terjadi dalam dunia Islam. Paham radikal di Labuhanbatu memiliki perspektif sendiri dalam melihat sebuah masalah, mereka berpaham sangat keras dan berbahaya, mereka menganggap orang kafir musuh dan sistem NKRI adalah sistem thogut. Yang membuat mereka berkembang juga terletak pada masyarakat yang kurang paham dengan ajaran Islamnya, maka dengan mudah mereka mendoktrinnya".

\section{Metode Komunikasi Dakwah MUI dalam Mengatasi Paham Radikal di Labuhanbatu}

Metode merupakan cara yang sangat dibutuhkan umat manusia, secara etimologi metode berasal dari bahasa yunani yakni dari kata "Metodos" bermakna "cara atau jalan" sedangkan menurut terminologinya metode adalah suatu proses atau cara sistematis yang digunakan untuk 
mencapai tujuan tertentu dengan efesien. Metode merupakan cara yang teratur untuk mencapai suatu maksud yang diinginkan. Dalam kajian ilmiah metode menyangkut masalah cara kerja untuk dapat memahami objek yang menjadi ilmu yang bersangkutan.

Sebagai contoh Nabi Muhammad SAW dalam melaksanakan dakwahnya dengan metode sembunyi-sembunyi, ketika malaikat jibril datang dan menyampaikan wahyu dan disitulah Rasulullah mendakwahi keluarganya dan orang yang terdekatnya secara sembunyi-sembunyi, sampai dakwah beliau diketahui oleh orang kafir quraisy.

Adapun bentuk metode komunikasi dakwah yang dilakukan MUI Labuhanbatu dalam mengatasi paham radikal:

\section{Metode Bil Hikmah}

Dalam pengertian yang sederhana, bikmah berarti adil dan bijaksana. Hikmah juga bisa berarti sabar, cermat dan teliti. Menurut Quraish Shihab bahwa para ulama mengajukan aneka keterangan tentang makna hikmah. Hikmah berarti yang paling utama dari segala sesuatu, baik pengetahuan maupun perbuatan. Ia adalah ilmu amaliah dan amal ilmiah. Ia adalah ilmu yang didukung oleh amal, dan amal yang tepat dan didukung oleh ilmu. Hikmah adalah sesuatu yang apabila digunakan, dipakai dan dipraktekkan akan menghalangi terjadinya mudharat, atau kesulitan, dan mendatangkan kemaslahatan dan kemudahan. Memilih perbuatan yang terbaik dan sesuai adalah perwujudan dari bikmah dan pelakunya dinamai hakim (bijaksana).

Hasil wawancara peneliti dengan bapak KH. Darwis Husin LC, sebagai ketua MUI Labuhanbatu menyatakan:

"Dakwah bukan merupakan suatu beban melaikan suatu kewajiban yang harus dilaksanakan setiap muslim dan muslimah, dakwah merupakan sebuah komunikasi yang disampaikan secara lisan dan non lisan kepada mad"u. walaupun demikian dakwah harus dilakukan dengan berbagai metode agar pesan dakwah akan lebih mudah dipahami oleh mad "u."

"Dengan berbagai persoalan yang dihadapi MUI Labuhanbatu untuk menyikapi segala jenis watak dan tingkahlaku masyarakat, ditambah lagi dengan organisasi Lingkar Study Generasi Islam (LSGI) yang berpaham radikal menurut laporan dari masyarakat setempat, MUI sendiri dalam menyampaikan isi pesan dakwah mengenai radikalisme kepada masyarakat dan terkhusus kepada organisasi LSGI ini, kami dari MUI melakukan metode bil-bikmah. Bijaksana merupakan jalan dalam meyampaikan pesan mengenai bahayanya paham 
radikal. Pesan yang kami sampaikan sesuai dengan Alquran dan Hadis, apa sebenarnya kekerasan dalam Islam dan bagaimana Islam bertindak keras dengan musuh, kami jelaskan dengan rinci kepada Muhammad Khadafi selaku aktor dari LSGI itu sendiri. "MUI menyampaikan kepada Muhammad Khadafi tentang surah an-nisa ayat 60 dan 76 itu sesuai dengan para ulama tafsir, MUI menyampaikan tentang ayat 60 menurut tafsir Ibnu Katsir, yang dikatakan thogut disini adalah sesuai dengan sebab turunnya ayat, bahwa ada seorang laki-laki anshar dan seorang laki-laki yahudi sedang bersengketa, lalu orang yahudi itu berkata, antara aku dan engkau ada Muhammad, dan laki-laki anshar itu berkata, antara aku dan engkau ada ka'bah.”

"Berbicara tengtang thogut itu bermacam-macam maknanya, ada yang mengartikan dukun-dukun, berhala dari jenis jin dan manusia, dan lainnya. Maka MUI membuka pola fikir saudara Muhammad Khadafi tentang NKRI yang disebut thogut, kembali kesejarah NKRI, NKRI itu didirikan oleh para ulama-ulama di Indonesia, sesuai dengan alquran dan hadis yang disusun di dalam pancasila: Ketuhanan Yang Maha Esa (katakanlah Muhammad dialah Allah yang Maha Esa. QS. Al-Ikhlas ayat: 1), Kemanusiaan Yang Adil dan Beradap (wahai oang-orang yang beriman, jadilah kamu penegak keadilan, menjadi saksi kerena Allah. QS. An-Nisa ayat: 135), Persatuan Indonesia (Kemudian kami jadikan kamu berbangsabangsa dan bersuku-suku agar kamu saling mengenal. QS. AlHujurat ayat: 13), Permusyawaratan (Sedang urusan mereka diputuskan dengan musyawarah antara mereka. QS. Asy-Syura ayat: 38), Keadilan Sosial (Sesungguhnya Allah menyuruh kamu berlaku adil dan berbuat kebajikan.QS. An-Nahl ayat: 90).

Pernyataan di atas juga didukung oleh bapak DRS. H. Abdul Hamid Zaid, sebagai seketaris jendral MUI Labuhanbatu menyatakan:

"Kepada Muhammad Khadafi selaku pendiri dan pembina organisasi LSGI ini, MUI juga memberikan pembinaan mengenai paham yang mereka anut dengan sabar dan teliti, Muhammad Khadafi juga korban dari pencucian pemahaman radikal yang ia peroleh dari pengajian ketika ia duduk dibangku SMA, Muhammad Khadafi dan pengurus LSGI tidak dipenjarakan akan tetapi di karantinakan ditempat Badan Kepegawaian Pendidikan dan Pelatihan yang beralamat di jalan H. A. Idris No 1 untuk mengulang apa yang 
mereka dapat dari ustad mereka dan diluruskan pemahamannya."

"Setelah MUI telusuri lagi apa penyebab utama LSGI menyampaikan pemahaman radikal, jawaban Muhammad Khadafi ialah mereka ingin membentuk suatu negara yang berlandaskan sesuai yang dilakukan oleh Nabi Muhammad SAW, dan mereka merasa dinegaranya sendiri tidak mendapatkan keadilan dan maraknya penindasan terhadap nilainilai ke-Islaman di Indonesia dan di seluruh dunia. Walaupun demikian LSGI tetap salah dalam mengamalkan ajaran keIslamannya, MUI terus melakukan pembinaan dan kontrol di masyarakat agar tidak semakin meluas ajaran radikalisme ini'

Untuk melengkapi data di atas, peneliti mendatangi bapak Syafruddin bagian humas polres Labuhanbatu, bapak Syafruddin menyatakan:

"Pihak kepolisian polres Labuhanbatu membenarkan memang ada organisasi yang ekstrim dan berpaham radikal di Labuhanbatu yaitu LSGI, organisasi ini didirikan pada tanggal 14 juni 2012 oleh seorang pemuda yang bernama Muhammad Khadafi, beliau adalah seorang pedagang es kelapa di jalan Perisai dan rumah beliau beralamat di jalan Binaraga Rantauprapat”.

"Organisasi ini disebut berpaham radikal setelah ada masyarakat di jalan Binaraga melaporkan ke MUI dan MUI melaporkan ke pihak kepolisian polres Labuhanbatu, isi dari pengajian mereka itu sangat membahayakan kerukunan ummat beragama, tentang thogut, LSGI menyatakan sistem NKRI yang idiologinya Pancasila dan UUD 1945 adalah thogut dan bukan bersumber dari hukum Islam, melainkan hukum buatan manusia, dan mereka sangat anti terhadap orang-orang kafir."

"Polres Labuhanbatu mengambil sikap dengan mengirim intel ketempat dimana mereka mengadakan pengajian itu, pengintaian itu berlangsung selama tiga hari dari tanggal, 3,6,8 desember 2018, hasil dari pengintaian itu berhasil dan LSGI ditetapkan sebagai organisasi yang berpaham radikal, maka polres Labuhanbatu dan MUI Labuhanbatu bekerjasama untuk menindak lanjuti organisasi ini."

"MUI sendiri meluncurkan sebuah surat permohonan kepolres yang berisi agar seluruh anggota LSGI dibimbing ulang, karena 
seluruh anggotanya adalah anak dibawah umur yang masih bersekolah di SMP dan SMA yang pemahaman tentang Islamnya pasti sangat minim, dan juga membimbing Muhammad Khadafi selaku eksekutor LSGI, maka polres memenuhi permohonan MUI itu agar mereka dibimbing di Badan Kepegawaian Pendidikan dan Pelatihan yang beralamat di jalan H. A. Idris No 1.

Peneliti melihat metode bil bikmah yang dilakukan oleh MUI Labuhanbatu adalah ketika MUI meluncurkan surat permohonan agar semua anggota LSGI dibimbing dan diberi nasehat, MUI tidak mengambil sikap yang kasar agar mereka dibiarkan dan ditangkap oleh densus 88, sikap ini adalah cerminan dari Bil-Hikmah, yaitu bijaksana dalam mengambil keputusan yang tepat untuk korban pencucian paham radikal, apalagi untuk Muhammad Khadafi yang berusia masih muda berumur 26 tahun.

\section{Metode Mauizatul Hasanah}

Secara bahasa, Mau"iß̧hah hasanah terdiri dari dua kata, yaitu mau"izhah dan hasanah. Kata mau" i₹̧hah berasal dari kata wa"adqa-ya"id₹uwa"dzan-,idzatan yang berarti; nasehat, bimbingan, pendidikan dan peringatan. Sementara hasanah merupakan kebalikan dari sayyi"ah yang artinya kebaikan lawannya kejelekan.

Hasil wawancara peneliti dengan bapak DRS. H. Abdul Hamid Zaid, sebagai seketaris jendral MUI Labuhanbatu menyatakan:

"Menjalani praktik dakwah untuk membangun idiologi para aktivis LSGI agar mengenal Islam lebih harmonis, bukan segampang membalikkan kedua telapak tangan, disana sini pasti ada kendala dan rintangan, bagi MUI selaku pendakwah atau $\mathrm{da}^{\text {ee }} i$ memang memerlukan jiwa yang besar dalam mengarungi berbagai macam masalah terlebih masalah paham LSGI yang radikal ini, metode yang tetap juga harus dilakukan MUI adalah metode mau izatul hasanah."

"Untuk metode ini, kami dari MUI sendiri sudah melakukan dakwah dengan memberi peringatan, nasihat, dan bimbingan kepada para aktivis LSGI dan kepada Muhammad Khadafi, di Badan Kepegawaian Pendidikan dan Pelatihan yang beralamat di jalan H. A. Idris No 1. Pendidikan ini berlangsung selama satu minggu dari tanggal, 25-31 maret 2019."

"Sikap yang diambil oleh MUI ini bukan karena tergesa-gesa melaikan MUI tidak berkeinginan LSGI ini semakin luas menyebarkan pemahamannya, target dari ekspansi LSGI ini adalah 
anak remaja yang berstatus sekolah yang paling mudah disusupi paham radikal. Dengan bekerjasama melalui dinas pendidikan dan kementrian agama, kami membuat traning, dengan maksud para remaja ini paham apa sebenarnya radikalisme itu dan dan apa ciricirinya. Pembinaan yang kami buat bukanlah untuk memusuhi Muhammad Khadafi dan para rekan-rekannya yang lain, akan tetapi untuk meluruskan pemahaman yang telah ditanamkan selama ini oleh murobbinya."

Pernyataan di atas juga didukung oleh bapak KH. Darwis Husin LC, sebagai ketua MUI Labuhanbatu menyatakan:

"Mau"izatul Hasanah yang dilakukan MUI adalah dengan melakukan pendekatan kepada Muhammad Khadafi dan LSGI, memudahkan mereka untuk tidak diproses oleh hukum lebih lanjut, kalau mereka mau merubah idiologi mereka apasalahnya MUI membimbing mereka ke jalan Islam yang rahmatal lilealamin, bukan Islam yang memusuhi orang yang tidak sepaham dengan mereka, dan LSGI bukan untuk dimusuhi dan diasingkan, LSGI juga belum melakukan langsung kekerasan, akan tetapi mereka hanya menyampaikan paham mereka ke masyarakat melalui organisasi ini.”

"Metode mua"izatul hasanah ini juga dilakukan oleh Rasulullah ketika wahyu pertama turun dan Rasul memberi peringatan kepada istri, keluarga, dan teman dekatnya dengan sembunyi-sembunyi, sampai akhirnya dakwah secara terang- terangan, memberi nasihat, peringatan dan juga bimbingan kepada kaum quraisy, Rasul berhasil menaklukkan tanah arab dengan ajaran islam, sampai islam dikenal diseluruh dunia."

Peneliti melihat metode Mau"iratul Hasanah yang dilakukan oleh MUI Labuhanbatu adalah ketika MUI melakukan pendekatan interpersonal kepada Muhammad Khadafi dan anggota LSGI, mereka diberi nasehat, pendidikan dan peringatan tentang apa yang mereka pahami selama ini tentang Islam yang berlaku ekstrim, LSGI tidak dimusihi dan diasingkan di Labuhanbatu.

\section{Metode Mujadalah Billati Hiya Ahsan}

Menurut tafsiran an-Nasafi kata, Mujadalah billati biya absan, Berbantahan yang baik yaitu dengan jalan yang sebaik-baiknya, antara lain dengan perkataan yang lunak, lemah lembut, tidak dengan ucapan yang kasar, atau yang mempergunakan sesuatu (perkataan) yang bisa 
menyadarkan hati, membangunkan jiwa dan menerangi akal pikiran, ini merupakan penolakan bagi orang-orang yang enggan melakukan perdebadatan dalam agama.

Hasil wawancara peneliti dengan bapak DRS. H. Abdul Halim Hasan.MH, sebagai ketua seksi dakwah MUI Labuhanbatu menyatakan:

"Metode mujadalah merupakan sebagian dari dakwah yang dilakukan MUI kepada Muhammad Khadafi dan LSGI, selama pembinaan yang dilakukan MUI terhadap Muhammad Khadafi dan LSGI, MUI membantah pernyataan Muhammad Khadafi dalam surah Albaqarah ayat 190 yang artinya" Dan perangilah di jalan Allah orangorang yang memerangi kamu, tetapi janganlah kamu melampaui batas, karena sesungguhnya Allah tidak menyukai orang-orang yang melampaui batas. (Q.S Al-baqarah ayat: 190)".

"Ayat ini adalah salah satu rujukan mereka juga untuk melakukan tindakan radikal, karena kata mereka surah Al-baqarah ayat 190 ini berkaitan dengan surah An-nisa ayat 60 dan 76 yang membahas tentang thogut, sebuah hukum yang bersumber dari manusia bukan hukum Allah maka itu disebut thogut, dan para tgohut ini harus diperangi maka NKRI termasuk kedalam kategori thogut, tutur Muhamad Khadafi. Maka dalam menanggapi pernyataan Muhammad Khadafi ini, MUI melakukan metode Mujadalah yaitu membantah pernyataan saudara Muhammad Khadafi dengan melihat tafsir Ibnu Katsir dalam surah Al-baqarah ayat 190 itu".

"MUI mengatakan bahwa ayat ini bukan semata-mata untuk memusuhi orang yang kita anggap salah, asbabun nuzul ayat ini menerangkan dalam suatu riwayat ditemukan bahwa ayat ini turun berkenaan dengan perdamaian di Hudaibiyah, yaitu ketika Rasulullah dicegat oleh kaum quraisy untuk memasuki Baitullah, adapun isi perdamaian tersebut antara lain, agar kaum muslimin menunaikan umrah pada tahun berikutnya. Ketika Rasulullah beserta para sahabatnya mempersiapkan diri untuk melaksanakan umrah sesuai dengan perjanjian, para sahabat khawatir kalau orang quraisy tidak menepati janjinya."

Muhammad Khadafi dan teman-temannya mendengar dengan hikmat apa yang dijelaskan oleh MUI, apa yang mereka pahami sangat berbeda sekali dengan apa yang MUI sampaikan, ayat 190 itu mereka keliru untuk menafsirkannya tanpa melihat terlebih dahulu tafsir-tafsir 
yang ada, resikonya mereka akan terpengaruh dengan ayat yang teksnya belum bisa dipahami dengan benar dan akhirnya mereka menyimpulkan sendiri."

Pernyataan di atas juga didukung oleh bapak KH. Darwis Husin LC, sebagai ketua MUI Labuhanbatu menyatakan:

"Metode Mujadalah ini sangat efektif untuk Muhammad Khadafi dan teman- temannya, kerena dengan metode ini MUI langsung bertatap muka dengan mereka, MUI juga menjelaskan kepada mereka apa sebenarnya jihad di dalam Islam itu, dalam surah Al-furqon ayat 52 Allah berfirman yng Artinya: Maka janganlah kamu mengikuti orangorang kafir, dan berjihadlah terhadap mereka dengan Alquran dengan jihad yang besar (Q.S Al-furqon. Ayat:52".

"MUI menjelaskan kepada Muhammad Khadafi dan kepada pengurus LSGI bahwa ayat ini memiliki tafsiran tentang jihad dan bukan tentang kekerasan semata, dalam tafsir Zubdatut Tafsir Min Fathil Qadir (Syaikh Dr. Muhammad Sulaiman Al asyqor, Muddaris tafsir Universitas Islam Madinah) memerangkan makna ayat di atas. Bersungguh-sungguh dalam dakwahmu dan jangan taati hawa nafsu dan kepalsuan orang-orang kafir. Berjihadlah dengan jihad yang besar terhadap mereka menggunakan Alquran, karena berjihad menggunakan hujjah dan bukti-bukti kebenaran itu lebih besar daripada berjihad menggunakan pedang."

"Penjelasan di atas sudah membuat Muhammad Khadafi tidak berkutik sedikitpun dan tidak ada pembantahan yang ia keluarkan, MUI sadar ia juga korban dari pencucian paham yang keliru yaitu radikalisme, dengan bergantinya waktu sampai pada hari terakhir bimbingan dan nasehat yang MUI lakukan pada tanggal 31 maret 2019, Muhammad Khadafi dan para pengikutnya menyatakan permohonan maaf kepada MUI dan juga masyarakat setempat khususnya di Labuhanbatu dan pihak kepolisian dan pemerintahan setempat, mereka berjanji tidak akan mengulangi kesalahan ini lagi, dan mereka bermohon agar MUI mau membimbing mereka bukan hanya dalam masalah radikal ini saja, melainkan tentang Islam yang mereka belum mengetahui sepenuhnya."

Peneliti melihat metode Mujadalab yang dilakukan oleh MUI Labuhanbatu sangat efektif dan berjalan sesau dengan harapan, disini MUI berhasil mengubah Muhammad Khadafi dan anggota LSGI dengan 
penjelasan ayat-ayat yang telah disampaikan, MUI juga membantah ayatayat yang dilontarkan oleh Muhammad Khadafi yang mengandung makna thogut dan jihad, penjelasan sudah tetap dan benar dengan melihat para ulama-ulama tafsir, dan pada akhirnya Muhammad Khadafi meminta maaf depada semuanya, atas kesalahan yang ia bawa dan menyebarkannya di Labuhanbatu.

\section{Tingkat Keberhasilan MUI dalam Mengatasi Paham Radikal di Labuhanbatu}

Setiap usaha yang kita lakukan pasti memiliki feetback yang bernilai positif maupun negatif, sama halnya jika seseorang selalu berbuat kebaikan dalam hidupnya maka di akhirat kelak dia akan mendapat kegahagian, begitu juga sebaliknya, jika seseorang selalu berbuat keburukan maka di akhirat kelak dia akan mendapat azab yang pedih atau siksaan. Begitu juga dengan dakwah yang dilakukan MUI dalam mengatasi paham radikal yang dilakukan LSGI di Labuhanbatu Rantauprapat, apakah tingkat pengaplikasiannya sukses atau tidak.

MUI ketika berdakwah berhasil membuat Muhammad Khadafi dan para pengikut LSGI mau mengikuti dan menerapkan isi dari pesan dakwah yang disampaikan. MUI secara tidak langsung mengubah pengetahuan, sikap, dan peningkatan amal Muhammad Khadafi dan LSGI yang salah menjadi benar. Maka MUI tadi sudah berhasil dalam menyampaikan pesan dakwah. Di bawah ini akan dipaparkan dengan jelas tingkat keberhasilan dakwah yang dilakukan oleh MUI yang berkaiatan dengan tiga metode komunikasi dakwah di atas:

Hasil wawancara peneliti dengan bapak DRS. H. Abdul Halim Hasan.MH, sebagai ketua seksi dakwah MUI Labuhanbatu menyatakan:

\section{Perbaikan Persepsi}

"Persepsi ialah sebuah pandangan atas segala sesuatu, dari yang tidak paham menjadi paham. Dalam penerapan dari tiga metode komunikasi dakwah di atas, alhamdulillah MUI berhasil memberi pendangan kepada Muhammad Khadafi dan anggota LSGI tentang masalah thogut dan jihad dalam Islam, 100\% anggota LSGI sudah tidak tertarik dengan mengikuti pemahaman yang di ajarkan oleh Muhammad Khadafi."

Pernyataan di atas juga didukung oleh bapak KH. Darwis Husin LC, sebagai ketua MUI Labuhanbatu menyatakan:

"MUI sejauh ini berhasil dalam menjalankan dakwah secara Hikmah, Mau" izatul dan Mujadalah, dengan mengubah persepsi mereka yang selama ini berpaham sangat esktrimis, dahulu mereka menganggap yang disampaikan Muhammad Khadafi itu benar sesuai dengan ayat- 
ayat dalam Alquran dan Hadis. Tetapi mereka salah, setelah MUI memberikan penjelasan mengenai ayat-ayat jihad dan dan thogut."

"Peningkatan ini bukanlah suatu kebanggaan yang membuat MUI berhenti disini saja, akan tetapi MUI harus lebih ekstra dalam penyebaran dakwah, masalah radikal bukanlah hanya masalah MUI saja, yang bertanggung jawab adalah pemerintah, masyarakat, beserta para tokoh ulama, kita tidak tahu kedepan seperti apa masalah radikal ini akan muncul, himbauan MUI kepada masyarakat: mari samasama kita cekal paham radikal di wilayah kita, jika ada suatu pengajian yang berarah kepada kekerasan dan bom bunuh diri, maka loporkan depada pihak kepolisian dan MUI Labuhanbatu."

\section{Perbaikan Sikap Menjadi Lebih Baik}

Hasil wawancara peneliti dengan bapak DRS. H. Abdul Hamid Zaid, sebagai seketaris jendral MUI Labuhanbatu menyatakan: "Sikap merupakan suatu hasil dari seseorang berinteraksi dengan yang lain bisa dengan lingkungan, belajar, dan perubahan sosial yang mempengaruhinya. Jika seseorang berinteraksi dengan orang yang salah, maka tidak disadari sikap orang tersebut akan menjadi salah, begitu juga dengan sebaliknya, jika seseorang berinteraksi dengan orang yang benar, maka sikap orang tersebut akan benar dengan tingkahlakunya."

"Keberhasilan MUI dalam membentuk sikap Muhammad Khadafi dan anggota LSGI yang berpemahaman radikal sejauh ini sudah kembali kepada kepemahaman Islam yang tidak memakai kekarasan dan permusuhan, mereka sudah aktif kembali bermasyarakat setelah menjalani bimbingan dari MUI, dan menjalani interaksi sosial, sebelum itu mereka tidak mau berinteraksi kepada masyarakat di sekitarnya."

Untuk melengkapi data di atas, peneliti mendatangi bapak Syafruddin bagian humas polres Labuhanbatu, bapak Syafruddin menyatakan:

"Kerja keras yang dilakukan MUI dalam membina Muhammad Khadafi dan LSGI tidaklah sia-sia, setelah mereka meminta maaf kepada pemerintah, kepolisian, MUI dan masyarakat dan mereka dibebaskan bersyarat, agar tidak melakukan paham yang ekstrimis di Labuhanbatu dan di sekitar NKRI. Polres Labuhanbatu sendiri tidak segampang itu melepaskan mereka, pihak Polres mengirin anggota intel untuk melihat 
Muhammad Khadafi di kediamannya sedang melakukan apa, sampai saat ini memang Muhammad Khadafi dan LSGI tidak lagi beroperasi, Muhammad Khadafi juga melakukan aktifitas berjuan di jalan Perisai. Tidak ada tanda-tanda yang mencurigakan.

\section{Perbaikan Sosial}

Hasil wawancara peneliti dengan bapak DRS. H. Abdul Halim Hasan.MH, sebagai ketua seksi dakwah MUI Labuhanbatu menyatakan:

"Manusia itu adalah makluk sosial yang salin membutuhkan dan mempunyai keperluan terhadap orang lain. Islam sendiri sudah menerangkan di dalam alquran tentang interaksi sosial." Allah berfirman dalam surat Al-Hujurat ayat: 13 yang artinya: Artinya: Hai manusia, sesungguhnya kami menciptakan kamu dari seorang lakilaki dan seorang perempuan dan menjadikan kamu berbangsa-bangsa dan bersuku-suku supaya kamu saling kenal mengenal. Sesungguhnya yang paling mulia diantara kamu di sisi Allah ialah yang paling bertaqwa diantara kamu. Sesungguhnya Allah maha mengetahui lagi maha mengenal."

"Sejauh yang MUI lihat Muhammad Khadafi interaksi sosialnya kurang terhadap masyarakat setempat, mereka lebih sering berinteraksi dengan satu organisasi mereka, dan juga berinteraksi dengan anak remaja yang akan mereka tarik dan mengikuti pengajian mereka."

"Alhamdulillah, Muhammad Khadafi yang dulu memiliki paham radikal itu, sekarang sudah kembali lagi untuk bermasyarakat dan berinteraksi sosial seperti orang lain pada umumnya. Sebenarnya Muhammad Khadafi tidak mau berinteraksi sosial dikarenakan hati dan pikirannya tidak lagi sejalan dengan masyarakat dan juga dalam masalah agama, itulah yang menutupi dirinya untuk berinteraksi."

\section{Perbaikan Budaya}

Hasil wawancara peneliti dengan bapak KH. Darwis

Husin LC, sebagai ketua MUI Labuhanbatu menyatakan:

"Tidak kita pungkiri bahwasanya bangsa indonesia memiliki beragam kebudayaan dan suku, bukan hanya di indonesia saja, semua negara pasti memiliki budaya masing masing, masyarakat indonesia dikenal dengan keremah 
tamahannya dan tegur sapa, ini sudah menjadi ciri khas masyarakat kita."

"Pantauan MUI terhadap Muhammad Khadafi, MUI menemui Muhammad Khadafi sudah meninggalkan kebudayaan indonesia yang ciri khasnya ramah tamah, laporan masyarakat setempat kapada MUI bahwa Muhammad Khadafi jarang bergaul, dan ketika berjumpa tidak mau menegur dan sapa menyapa kepada masyarakat setempat. Dan alhamdulillah Muhammad Khadafi setelah dibina oleh MUI kini ia sudah mau bergaul, tergur menegur dan saling menyapa kepada masyarakat setempat'.

Keberhasilan yang dilakukan MUI dalam mengatasi paham radikal yang dibawa oleh Muhammad Khadafi memalui organisasi LSGI di Labuhanbatu tentulah ada aspek-aspek yang harus dilakukan MUI dalam penerapan metode komunikasi dakwah:

\section{Pembinaan}

Hasil wawancara peneliti dengan bapak DRS. H. Abdul Halim Hasan.MH, sebagai ketua seksi dakwah MUI Labuhanbatu menyatakan:

"Ketika MUI menjalankan aktivitas dakwah dengan penerapan yang metode komuniksi dakwah di atas, MUI melakukan pembinaan kepada Muhammad Khadafi, pembinaan disini adalah memberikan nasehat, pendidikan selama satu minggu dari tanggal 25-31 maret 2019, dan lokasi pembinaannya di Badan Kepegawaian Pendidikan dan Pelatihan yang beralamat di jalan H. A. Idris No 1. Pembinaan ini dilakukan untuk merubah pola fikir dan sikap Muhammad Khadafi yang radikal agar tidak lagi membahayakan masyarakat terlebih orang non Islam dan kepolisian."

"MUI mengatakan bahwasanya pembinaan ini adalah mencuci fikiran Muhammad Khadafi dan para anggota di LSGI kembali untuk tidak berfikir radikal memusuhi yang mereka anggap salah, serta menghapus memori fikiran mereka yang selama ini merusak tatanan kerukunan umat beragama di Labuhanbatu dan juga di sekitarnya".

\section{Pengawasan}

Hasil wawancara peneliti dengan bapak DRS. H. Abdul Hamid Zaid, sebagai seketaris jendral MUI Labuhanbatu menyatakan:

"Setelah pembinaan dilakukan, Muhammad Khadafi dan anggota LSGI meminta maaf kepada selurunya elemen pemerintahan dan 
masyarakat khususnya di Labuhanbatu. mereka di bebaskan bersyarat, dengan syarat tidak melakukan lagi paham yang radikal itu maupun menyebarluaskannya. Dan mereka bisa kembali lagi dengan keluarga mereka masing-masing. Walaupun begitu MUI tetap melakukan pengawasan terhadap mereka bekerja sama dengan kepolisian dan masyarakat setempat yang bersifat rahasi, bukan berarti mereka di kembalikan tanpa pengawasan".

Peneliti mendatangi bapak Syafruddin bagian humas polres Labuhanbatu, bapak Syafruddin menyatakan tentang pengawasan:

"Pihak kepolisian juga melakukan pengawasan dengan menyadap hp Muhammad Khadafi agar kepolisian mengetahui dari mana saja telepon masuk dan membicarakan hal tentang apa, dari sini kami akan mengetahuinya, pihak intel juga sedang memata- matai Muhammad Khadafi sehari-hari.

\section{Faktor Hambatan yang Ditemukan Oleh MUI Dalam Mengatasi Paham Radikal di Labuhanbatu dan Solusi Untuk Mengatasinya}

Setiap bentuk kegiatan yang dilakukan oleh manusia, secara sadar atau tidak pasti akan mendapatkan suatu kendala atau hambatan. Hambatan atau masalah yang dihadapi sering menghambat untuk menyelesaikan kegiatan yang dilangsungkan. Namun sebaliknya problem bukan untuk dihindari, karena problem tetap selalu mengiringi kehidupan manusia.

Berkenaan dengan hambatan yang dihadapi oleh MUI dalam mengatasi Muhammad Khadafi dan para anggota LSGI yang berpaham radikal di Labuhanbatu, sebenarnya bukan masalah yang sangat prinsip, sebab semua masalah yang dihadapi dengan mudah diselesaikan. Namun demikian juga beberapa masalah penghambat dakwah yang dilakukan MUI. Adapun penghambatnya adalah:

\section{Aspek Agama}

Hasil wawancara peneliti dengan bapak KH. Darwis Husin LC, sebagai ketua MUI Labuhanbatu menyatakan:

"Agama merupakan kepercayaan yang dianut oleh seseorang, secara garis besar masyarakat dapat dibagi kepada golongan muslim dan non muslim. Kelompok muslim masih bisa dibedakan lagi kepada beberapa kelompok: Kelompok yang beragama dengan benar, yakni yang mengetahui, memahami, meyakini dan mengamalkan ajaran agama dalam segala aspek kehidupannya, Kelompok yang beragama secara formalitas, yakni mereka yang mengambil ajaran agama hanya dalam bentuk lahiriah saja dan Kelompok yang beragama sebatas nama, yakni mereka tidak pernah mengamalkan ajaran agamanya." 
Pernyataan di atas juga didukung oleh bapak DRS. H. Abdul Halim Hasan.MH, sebagai ketua seksi dakwah MUI Labuhanbatu menyatakan:

"Aspek agama juga sangat besar pengaruhnya terhadap usaha pembentukan kepribadian, tingkahlaku dan cara bertindak. Aspek agama ini juga mempengaruhi orang-orang yang akan direkrut oleh para aktivis LSGI dan Muhammad Khadafi, para

korban yang dulunya pemahaman tentang Islamnya kurang, dan ada mereka yang ingin berubah kejalan yang lebih baik mereka ikut pengajian LSGI yang berpahaman radikal, sebenarnya mereka tidak mengetahui pengajian itu berisi tentang kekerasan dan permusuhan terhadap orang kafir dengan dalih jihad."

"MUI menghimbau kepada seluruh masyarakat di Labuhanbatu yang ingin berubah kejalan yang lebih baik, maka lihatlah isi dari pengajiannya, jika isi pengajiannya mengandung unsur kebencian, permusuhan terhadap orang-orang kafir, maka jangan lagi diikuti pengajian itu, segera lapor kepada MUI dan pihak kepolisian Labuhanbatu agar bisa ditindak lanjuti."

Hambatan dakwah yang dilakukan oleh MUI Labuhanbatu dalam mengatasi persoalan Muhammad Khadafi dan anggota LSGI yang berpaham radikal, bukanlah suatu prinsip yang tidak bisa diselesaikan, dengan ijin Allah dakwah tetap berjalan dengan semestinya. Adapun cara perbaikan (solusi) untuk mengatasi hambatan tersebut adalah:

Hasil wawancara peneliti dengan bapak KH. Darwis Husin LC, sebagai ketua MUI Labuhanbatu menyatakan:

a) Dengan menegakkan kewajiban kita kepada Allah dan memperkuat iman di hati, khususnya masyarakat disarankan untuk memperdalam ilmu tentang Islam, seperti mengikuti pengajianpengajian yang bersifat terbuka untuk umum, melihat vidio ceramah di youtube seperti ceramah ustad abdul somad dan lain sebagainya, jadi wawasan kita tentang Islam bisa meluas, adapun paham radikal yang mau mengajak kita untuk bergabung, kita bisa memprotesnya."

b) Partisipasi dari pemerintah dan lembaga kemitraan, partisipasi dari berbagai pihak yang mendukung sangat berperan besar dalam terlaksananya setiap kegiatan dakwah yang dilakukan MUI Labuhanbatu dalam memberantas paham radikal. Mulai dari 
pemerintah Labuhanbatu, kepolisian, tentara, lembaga pendidikan, dan lain-lain yang turut andil dalam setiap kegiatan dakwah MUI Labuhanbatu.

c) Sarana dan prasarana yang memadai, sangat dibutuhkan dalam berbagai kegiatan dakwah MUI Labuhanbatu dalam mengatasi paham radikal yang dilakukan oleh Muhammad Khadafi dan anggota LSGI. Sarana dan prasarana selalu dipersiapkan dengan mateng, akan menjadi memudahkan dakwah yang dilakukan MUI.

\section{UCAPAN TERIMA KASIH}

Ucapan terimkasih kepada MUI, Polres Labuhanbatu yang telah bersedia, memfasilitasi, dan membantu peneliti dalam penelitian ini yang berkaitan dengan memgatasi paham radikalisme di kota rantauprapat. Semoga informasi baik berupa data dan fakta yang diperoleh bermanfaat bagi peneliti dan masyarakat pada umumnya.

\section{DAFTAR REFERENSI}

Kementerian Agama RI. (2007). Al Quran dan Terjemahannya. Sigma Eksamadia Arkanleema.

Sabiq, S. (2015). Fiqih Sunnah. Al I'tishom.

Sugiyono. (2007). Metode Penelitian Pendidikan: Kuantitatif, Kualitatif, $R$ \& D. Alfabeta.

Sumbala, U. (2010). Radikal dan Pluralisme Agama. Badan Penlitan dan Pengembangan DIklat Kementerian Agama RI.

Wawancara dengan

\begin{tabular}{|l|l|l|c|}
\hline No & \multicolumn{1}{|c|}{ Nama } & \multicolumn{1}{|c|}{ Jabatan } & Usia \\
\hline 1 & Kh. Darwis husin. Lc & Ketua MUI Labuhanbatu & 61 Tahun \\
\hline 2 & Drs. H. Abdul Hamid Zaid & Seketaris MUI Labuhanbatu & 57 Tahun \\
\hline 3 & Drs. H. Abdul Halim Hasan.Mh & Seksi Dakwah MUI Labuhanbatu & 55 Tahun \\
\hline 4 & Bapak Syafruddin & Bagian Humas Polres Labuhanbatu & 50 Tahun \\
\hline
\end{tabular}

